\begin{tabular}{|l|c|c|}
\hline \multicolumn{2}{|c|}{ DJS Vol. 38 (2017) 210-218 } \\
\hline
\end{tabular}

\title{
Characterization of Silica Nanoporous Structures of Some Diatom Frustules and their Applications
}

\author{
Abdelfattah Ali Zalat*, Atef M. Abo - Shady**, Emad A. Al-Ashkar*** and Mohamed E. \\ Ghobara** \\ * Geology Department, Faculty of Science, Tanta University, 31527 Tanta, Egypt \\ (Email:abzalat@science.tanta.edu.eg) \\ ** Botany Department, Faculty of Science, Tanta University, 31527 Tanta, Egypt \\ (Email: atef.aboshady@science.tanta.edu.eg) \\ *** Spectroscopy Department, physics Division, National Research Center, Cairo, Egypt
}

\begin{abstract}
Diatoms are unicellular algae that belonging to the class Bacillariophyceae. They inhabit nearly all aquatic environments from marine to freshwater and moist habitats. These organisms create highly ornamented external siliceous shells of multi-layer structure with multi-scale porosity. The main objective of this study is to explore the utilization of diatom-derived porous structures in nanotechnology. The present study is based on five dominant species identified and described from 59 samples collected from different habitats in Egypt. The studied taxa included Actinocyclus cf. octonarius Ehrenberg, Aulacoseira granulata (Ehrenberg) Simonsen, Cyclotella meneghiniana Kützing and Pleurosira laevis (Ehrenberg) Compére. Nanoporous structures of the considered taxa have been well investigated through SEM analysis. The sizes of nanoporous silica were found in the range of 5 to $500 \mathrm{~nm}$. The obtained results showed the potential of diatoms as a source of natural silica micro-particles with micro- to nano-porous structures with prospective applications as supports for catalysis, selective adsorption, sensors, membranes, and other novel nanotechnological applications.
\end{abstract}

Key words: diatom frustules, nanoporous silica, nanotechnology applications.

\section{Introduction:}

Nanotechnology is the understanding and control of matter at dimensions of roughly 1 to 100 nanometers, where unique phenomena enable novel applications. The American Society for Testing and Materials (ASTM) defined Nanotechnology as a wide range of technologies that measure, manipulate, or incorporate materials and / or features with at least one dimension between 1 and 100 nm (ASTM, 2012). Nanotechnology has a growing market with medical, industrial, and military applications today. Such applications enable us to change the daily life style providing us with computers, smart phones, smart cars, smart houses, advanced military equipment, solar cells and medicinal creative solutions even better shampoos for hair health. The way to design and produce of nanoscale materials, structures, devices, and systems in scaled-up, reliable, and cost-effective manner is called "Nanomanufacturing" (Nano.gov, 2015).
Although all the benefits of Nanotechnology, there are several problems to solve; including environmental issues and non-biodegradable nanomaterial fate in the environment, energy costs of Nano-manufacturing processes, suitability of Nano-manufacturing technique and production rate (Naidu, 2012). Due to these reasons, there's a must for finding new nano-manufacturing techniques. Biology and nano-techniques present inside the living cells of some organisms could be the answer or a source for inspiration of nanotechnology, since the most of cellular molecular mechanisms take place in the nanoscale (Drexler, 1986).

Diatoms are the most important organisms that can be employed and introduce excellent material for nanotechnology. These microorganisms occur in almost all aquatic habitats (such as Oceans, seas, lakes, rivers, 
streams, ponds, pools, reservoirs springs and waterfalls). They are important for global ecosystem as primary producer for large portion of organic carbon and oxygen that we breathe (Mann, 1999). Moreover, there are more than 200,000 diatom species with various distinct architectures were recognized (Round et al. 1990). Diatoms build their cell walls from hydrated silica to produce a robust structure that called "Frustule". These frustules have unique and interesting porous silica architectures with inherited nano-details. So, Electron microscopy is needed to see the three dimensional structure of diatom frustules.

Diatom nanotechnology is the study of utilization of diatoms or their silica forming processes to make Nanodevices. Diatom frustule showed potential in nanotechnology (Townley, et al. 2008, Gordon et. al, 2009, Gordon, 2010). The basic advantage of diatoms architectures for nanotechnology applications over products created by the standard Nano-manufacturing techniques is that diatoms grow exponentially, whereas ordinary Micro-electro-mechanical systems (MEMS) are manufactured in numbers that grow linearly with time. Therefore, diatoms are considered more suitable to commercial approach for applications based on architectures such as MEMS. Moreover, diatoms will provide us with huge catalogue for different structures and parts that will make it easier to select from available species or attempt to genetically or environmentally modify their morphogenesis to produce the final desired design (Crawford et al. 2001; Gordon \& Parkinson, 2005).

Several functioning diatom based applications had been reported in the literature. Many works are reported diatom frustules as active component in Drug delivery systems, sensors (Dolatabadi and de la Guardia, 2011), Solar cells, batteries, electroluminescent devices, Lab on chip, templates, as natural photonic crystal slabs with waveguides (Fuhrmann et. al, 2004; Mishler et. al, 2014; Noyes et. al, 2008). Up to now, there is no any study to introduce diatom in nanotechnology application has been carried out in Egypt. The present study is considered the first contribution on the fine ultrastructure of some Egyptian diatom frustules by means of SEM and their applications in nanotechnology.

\section{Material and methods:}

The present work is based on 59 samples collected from 43 stations representing different habitats including marine, brackish and freshwater environments (Table 1 and Figure 1). The macrophytes, rocks and sediments were collected in plastic bags. All samples were stored in ice box, transferred to laboratory and stored at the refrigerator at $4{ }^{\circ} \mathrm{C}$ until use. Diatoms were extracted from 2 grams of dry sediments according to methods proposed by Zalat $(2000,2002)$ and Zalat and Servant Vildary (2005-2007). Approximately $20 \mathrm{ml}$ of HCL was added to the dry sample and then boiled on a hotplate for $30 \mathrm{~min}$. until all carbonate material removed. About $20 \mathrm{ml}$ of $30 \%$ hydrogen peroxide was added to the final previous suspension and boiled for about $20 \mathrm{~min}$. to eliminate the organic matter. The sample rinsing in distilled water several time to remove all acids and the suspension become neutral. Coarse particles were removed by further decantation (settling for 5 seconds). The sample was concentrated and stored in final volume of $50 \mathrm{ml}$ vial.

Approximately one drop or $0.1 \mathrm{ml}$ of the final suspension was distributed over a clean, dry coverslip (22 x $50 \mathrm{~mm}$ ) using a pipette and dried at low temperature. Diatom-coated cover-slips were placed on a hot plate at about $100^{\circ} \mathrm{C}$ for 5 minutes to remove the excess moisture and the residual ammonium chloride or ethanol. One or two drops of mounted media, such as Canada Balsam or DPX with refractive index ${ }^{\circledR}(\mathrm{R} . \mathrm{I}=1.67)$, were placed onto a clean slide then the cover slip lowered onto the glass slide, inverted, and then heated at $80-90{ }^{\circ} \mathrm{C}$.

The permanent slides were investigated to identify diatom taxa under phase contrast illumination using a Carl Zeiss photomicroscope with digital camera and $\mathrm{x} 63$ and $\mathrm{x}$ 100 oil immersion objective. Diatom identification was based mainly on the works of Hustedt (1957, 1930-1966), Ehrlich (1973, 1975), Simonsen (1979), Krammer and Lange-Bertalot (1986 - 1991a, b), Gasse (1986), Round et al. (1990), and Foged (1980, 1993). Sample material, the diatom slides and stubs are now part of the permanent Zalat diatom collection of the Geological Department, Tanta University, Egypt. The Scanning (SEM) are used to investigate the fine architecture and pore arrays of the cleaned diatom frustules. Diatom suspension was prepared to SEM by mounting on an aluminum microscope stub with carbon tape then sputter coated with gold. The coated coverslips were examined under high vacuum, $10-15$ $\mathrm{kV}$. SEM study was carried out by Field Emission scanning electron microscope (FE-SEM), Quanta FEG 250, FEI with EDAX in the electronic microscopic unit at National Research Center- Dokki- Egypt.

\section{Results and Discussion:}

Diatoms are formally classified as belonging to the Division Chrysophyta, Class Bacillariophyceae. They are traditionally classified into two groups, depending upon the valve symmetry: (i) the centric diatoms or centrales and the pennate diatoms or pennales. The centric group, which often has a circular symmetry and the valve striae arranged basically in relation to a point or a central areola and tend to appear radially symmetrical (Fig.2). The pennate group, which is usually elongate and bilaterally symmetrical with valve striae arranged in relation to a line (Fig.3).

Most of the examined samples contained sufficiently diatom taxa. Altogether, 237 species and varieties belonging to 68 genera were identified and counted from 59 samples collected from different habitats in Egypt. Scanning (SEM) is used to investigate the fine architecture and pore arrays of some dominant and cleaned diatom frustules selected from the identified taxa in the studied area. The studied diatoms are including two 
freshwater planktonic forms Aulacoseira granulata (Ehrenberg) Simonsen, Cyclotella meneghiniana Kützing; one brackish water taxon Pleurosira laevis (Ehrenberg) Compére, and one marine planktonic form Actinocyclus cf. octonarius Ehrenberg. The cleaned frustules of these taxa clearly showed the presence of fine nanoporous structures. The SEM images were analyzed by Digital Image Analysis software to illustrate pore diameter distribution in the studied species. Pores with dimensions ranging from 5 to $500 \mathrm{~nm}$ were found under SEM observations, suggesting the potentiality to use the diatoms in various nanotechnology applications. A brief overview of the pore architecture and overall structure of the studied diatom frustules are given here.

Table 1. Showing the locations of the studied sites and description of the samples

\begin{tabular}{|c|c|c|c|c|}
\hline $\begin{array}{l}\text { Location } \\
\text { No. }\end{array}$ & Location name & $\begin{array}{l}\text { No. of } \\
\text { samples }\end{array}$ & $\begin{array}{c}\text { No. } \\
\text { of } \\
\text { sites }\end{array}$ & $\begin{array}{c}\text { Description of the } \\
\text { samples }\end{array}$ \\
\hline I & $\begin{array}{c}\text { Mediterranean } \\
\text { Sea coast - } \\
\text { Alexandria, Egypt }\end{array}$ & 10 & 5 & $\begin{array}{l}\text { Epiphytic on } \\
\text { macrophyte, } \\
\text { Epilithic on the } \\
\text { rocks and } \\
\text { sediments }\end{array}$ \\
\hline II & $\begin{array}{l}\text { Red sea coast - } \\
\text { Hurghada, Egypt }\end{array}$ & 5 & 1 & $\begin{array}{l}\text { Epiphytic on } \\
\text { macrophyte }\end{array}$ \\
\hline III & $\begin{array}{c}\text { Manzala lake, } \\
\text { Egypt }\end{array}$ & 17 & 17 & surface sediments \\
\hline IV & Edku lake, Egypt & 6 & 6 & surface sediments \\
\hline V & $\begin{array}{l}\text { El-Kased canal - } \\
\text { Nile Delta, Egypt }\end{array}$ & 1 & 1 & $\begin{array}{l}\text { Planktonic in } \\
\text { Surface water }\end{array}$ \\
\hline VI & $\begin{array}{l}\text { El-Qudaba canal- } \\
\text { Nile Delta, Egypt }\end{array}$ & 7 & 5 & $\begin{array}{l}\text { Planktonic and } \\
\text { Epiphytic on } \\
\text { macrophyte }\end{array}$ \\
\hline VII-VIII & $\begin{array}{l}\text { Mit-Yazed canal- } \\
\text { Nile Delta, Egypt }\end{array}$ & 6 & 4 & $\begin{array}{l}\text { Planktonic and } \\
\text { Epiphytic on } \\
\text { macrophytes }\end{array}$ \\
\hline IX & $\begin{array}{l}\text { Fayoum } \\
\text { depression }\end{array}$ & 4 & 1 & Diatomite rocks \\
\hline
\end{tabular}

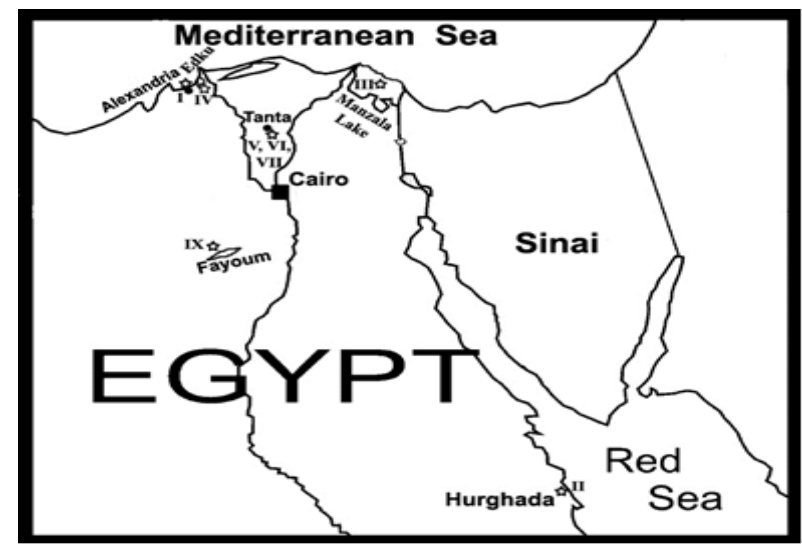

Figure 1: Location map showing the sampling sites.

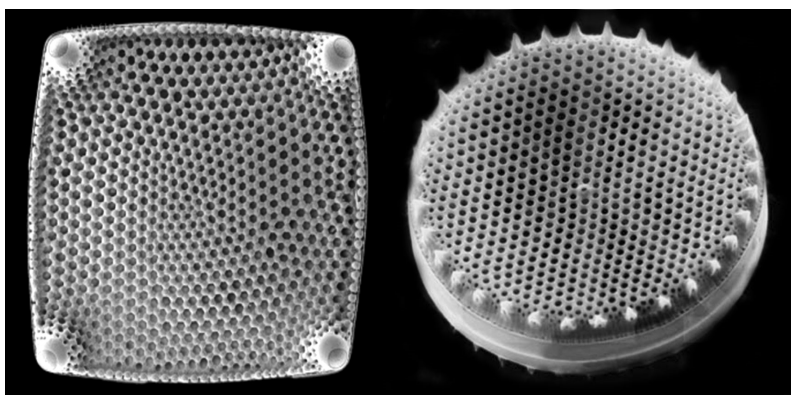

Figure 2: Centrals diatom group

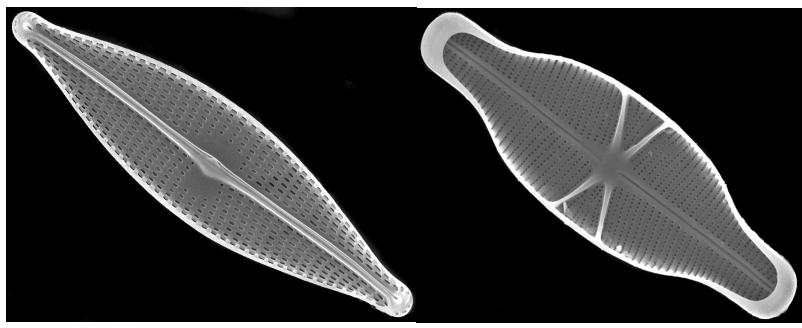

Figure 3: Pennales diatom group

\section{Description of the studied diatom species}

Aulacoseira granulata frustules are cylindrical, robust, bound in chains by thin spines. Pervalvar axis \pm stretched; neck short or moderately long; sulcus flat; pseudosulcus small. Surface of the mantle covered by areolae, coarse or fine, arranged in longitudinal spiral rows, about 5-14 in girdle view, and 9-10 spiral rows in $10 \mu \mathrm{m}$, areolae various in shape from 8 rounded to subrounded and angular, about 9-10 areolae per $10 \mu \mathrm{m}$. Valve diameter ranges between 5-20 $\mu \mathrm{m}$ and length about 9-14 $\mu \mathrm{m}$. 
The SEM micrographs (Fig. 4) show a strongly developed cylindrical mantle part of the valve, and flattened disci surface (valve face), which is curved slightly at the margin, to form small pseudosulcus. Surface of the disci is characterized by the presence of rimportulae, about 34 portulae at the margin, and also other fine pores placed at distance from each other near the rimportulae. Pores on the disci (valve face) appear to be finer than on the valve mantle. The cylindrical mantle wall is perforated by distinct areolae, which are varied in shape from rounded to quadrate, with diameter ranges between 450 to $500 \mathrm{~nm}$. Areolae are arranged in longitudinal, spiraled rows and only straight and parallel to the pervalvar axis at the end of each cell of one chain. Details of areolae show a membrane with very fine pores, which have diameters ranges from 40 to $50 \mathrm{~nm}$. Disci surface carries strong distinct spines on its margin; these spines are evenly spaced and uniform in size; 

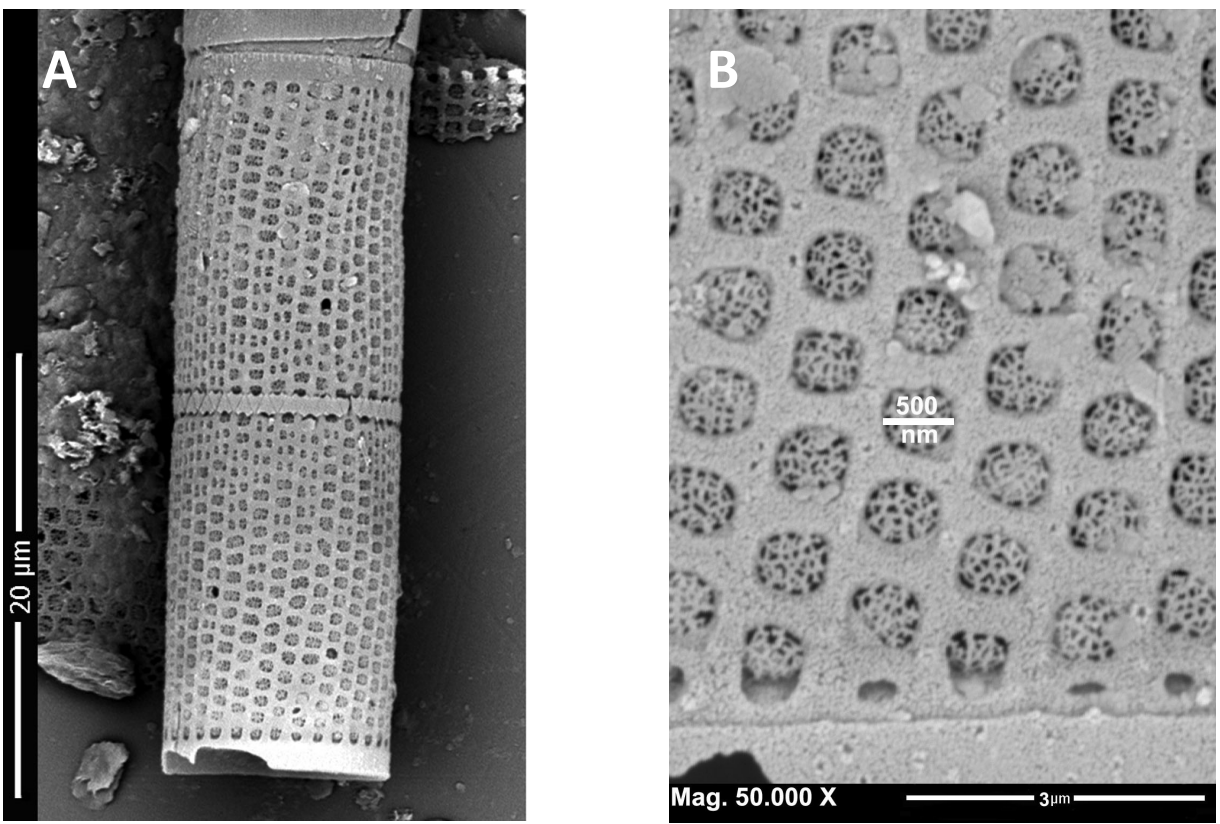

Figure 4: SEM micrographs of Aulacoseira granulata. (A) Full view of valve exterior; (B) detail surface of the valve showing nanoporous surface structure in exterior view.
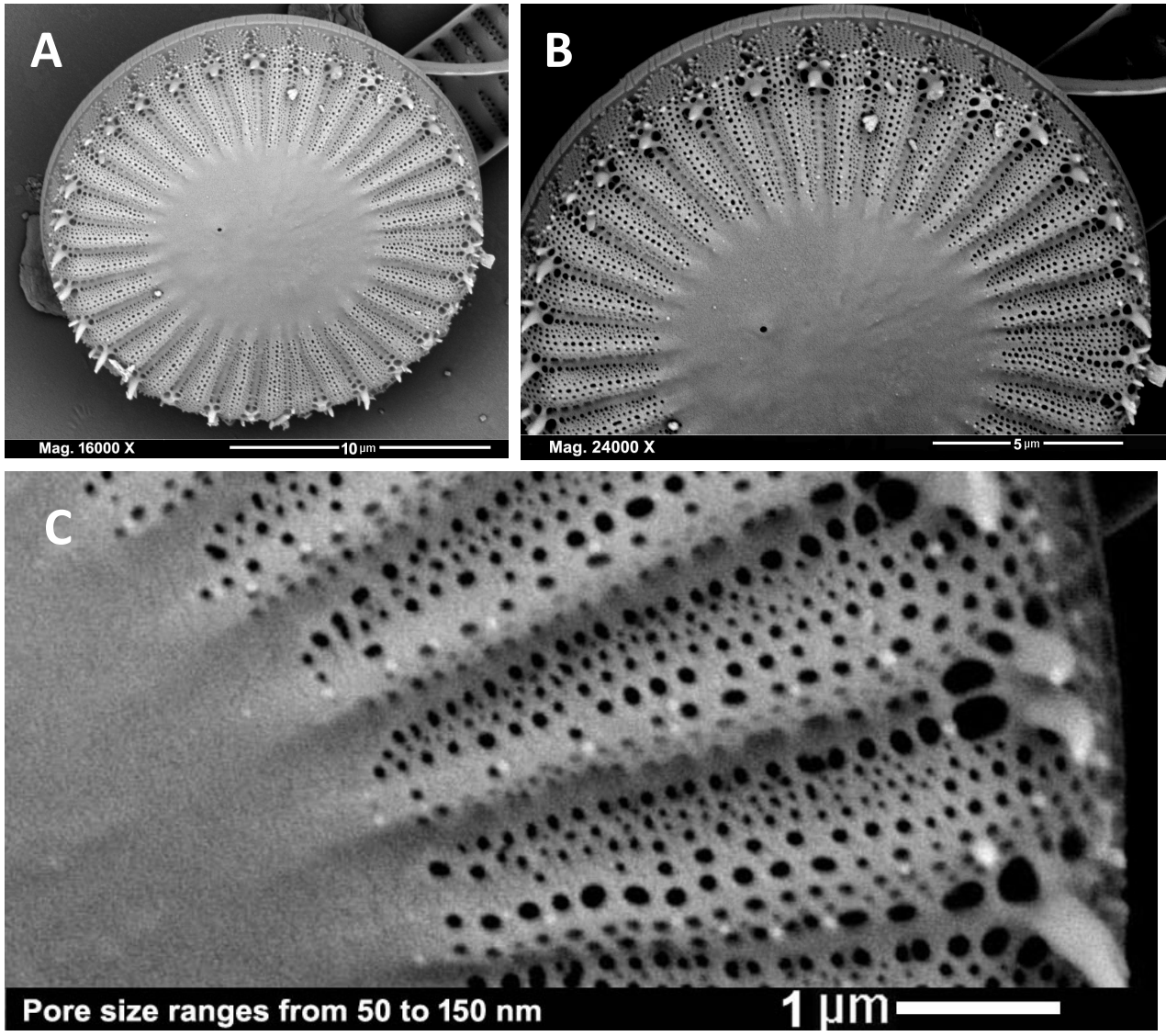

Figure 5: SEM micrographs of Cyclotella meneghiniana. (A) Full view of valve exterior; (B-C) detail surface of the valve showing nanoporous surface in external view. 
they are broader and capitate at the apex than at the base, and the two halves of different frustules attached together by these interlocking spines. Moreover, in some forms of Aulacoseira granulata the areolae on the mantle wall are arranged not in spiraled rows, but in straight lines and parallel to the pervalvar axis. These forms have valves in which the spines taper towards the apex and are of variable length. The long spines of one sibling valve lie within grooves in the other valve and the two valves fix together. In this case the two valves can be separated easily and the spines in these forms are formed by two amalgamating costae.

Cyclotella meneghiniana frustule appears cylindrical in girdle view, circular in valve face with more or less tangential undulating valve. Valve face is divided into two distinct zones; the outer part (marginal zone), which is radially striated; the radial striae are broad from the base at the margin, and gradually weaken and narrow toward the middle field; they are arranged regularly with 7-8 striae in $10 \mu \mathrm{m}$. The inner part, which is a non-areolated central area, it can either be smooth, unstructured with one or two punctae or ornamented by slightly radial ridges. Valve diameter ranges between 13-24 $\mu \mathrm{m}$.

SEM micrographs of the external valve view (Fig. 5 A-C) display that the mantle and part of the valve margin are well defined with radial striae, each one consisting of an areolated layer in the form of fascicle and a smooth layer of hyaline silica which form distinct radial ribs. The marginal areolated radial striae consist of three rows of fine pores, about 22-25 in one row, with average diameter ranges between 50 to $65 \mathrm{~nm}$ and alternated by another two rows of coarse pores, about 15-19 in one row with average diameter ranges between 80 to $150 \mathrm{~nm}$; these fine and coarse areolated radial striae are separated by a fine smooth layer of silica, which appears as a radial rib between them, and ending at the marginal rim, and in the distinct part of the mantle by a perforated layer arising from different sized fine and coarse pores, with several short and moderately long distinct spines scattered along the margin, and the mantle portion. Striae of pores are broader at the valve face/valve mantle junction than towards the center. The mantle fultoportulae are just beneath the spines at the fairly sharp angle of the mantle. The central area appears smooth or ornamented by fine undulating radial ribs. It carries one or two valve face fultoportulae with two satellite pores.

Actinocyclus cf. octonarius frustule is cylindrical, with intercalary bands; the valve face is circular, flat or slightly concave or convex. The diameter is $35-65 \mu \mathrm{m}$. The valve face has a characteristic areola pattern, which are positioned into sectors. The sectors are delimited on both sides by a single row of areolae, which are radial and reach the centre of the valve face. Central area is small with scattered isolated areolae. On the valve face 13-16 areolae in $10 \mu \mathrm{m}$ and $16-22$ on the valve mantle. Areolae run down straight on the valve mantle, parallel to the pervalvar axis. There are marked evenly spaced marginal rimoportulae, which are clearly visible on the curved outer surface of the mantle. The pseudonodulus is located above the openings of the rimoportulae close to the valve face/mantle junction. It has a slight depression and a larger opening than those of the rimoportulae. Valve mantle is about $1-2 \mu \mathrm{m}$ high, with vertical rows of fine areolae of about $23-25$ per $10 \mu \mathrm{m}$.

SEM micrographs showed that the areolae on the valve face are extremely rounded with diameter $200 \mathrm{~nm}$ (Fig. 6 A-B). The pseudonodulus is rounded with diameter of about $2 \mu \mathrm{m}$. A narrow hyaline ring is present on the boundary of the valve face and mantle. Marginal ring of rimoportulae are located in upper part of mantle; rimoportula internally with a relatively not high tube with arc-shaped slit or with a more or less straight slit in apical part; externally terminating by a small round opening.

Pleurosira laevis frustules occur as solitary or as colonies in straight or zigzag short chains. Frustules are rectangular in girdle view with almost straight sides, only a very small constriction and a narrow hyaline band. Frustules are either bi- or tripolar in valve view. Valve shape is circular to sub-circular, with almost a flat valve face, covered with fine simple areolae. The areolae are scattered, or arranged as uniseriate striae, radiating from the centre and continuing without a break down the mantle. Striae of about $15-17$ in $10 \mu \mathrm{m}$; Areola density is 14 to 18 in $10 \mu \mathrm{m}$. On the major axis of the valve surface at the outer margin are two large, almost circular short processes known as ocelli, which lie opposite one another and composed of fine rows of porelli (Fig. 7B). The ocelli are not the same size; one is much larger than the other. The two ocelli are usually lying on the valve rim and extend partly on to the valve face and partly on the mantle. The central part of the valve is furnished with two short spines, while the marginal part has numerous spinulae. The valve mantle is deep, and vertical, and frequently constricted where it meets the girdle. The girdle band is simple, sharply differentiated, appearing finely areolate. The valve diameter ranges between 50-96 $\mu \mathrm{m}$.

SEM micrographs showed that the valve has regular areolae that occur across the face and extend onto the mantle. The ocelli are usually elliptical, with $4-5 \mu \mathrm{m}$ in width and $10-15 \mu \mathrm{m}$ in length. The porelli that comprise the ocelli are small, closely spaced but form no recognizable pattern (Fig. 7B). The diameter of porelli ranges between 75 to $81 \mathrm{~nm}$. Internally, ocelli appear as depressions at the valve face/mantle junction.

\section{Significance of the studied diatom porous struct- ures in nanotechnology}

Diatom frustule has ornamented silica nanoporous structure, which seemed to have interesting functions beside the protection (Willis et al., 2010). The hierarchical porous structures that present in the studied frustules exhibit a wide scale range starting from $5 \mathrm{~nm}$ to $500 \mathrm{~nm}$. These porous structures, which appears as areolae usually occluded with membranous layer of pore occlusions as found in the Aulacoseira granulata (Fig. 4 A-B). The pore occlusions patterns, their distribution and average size 

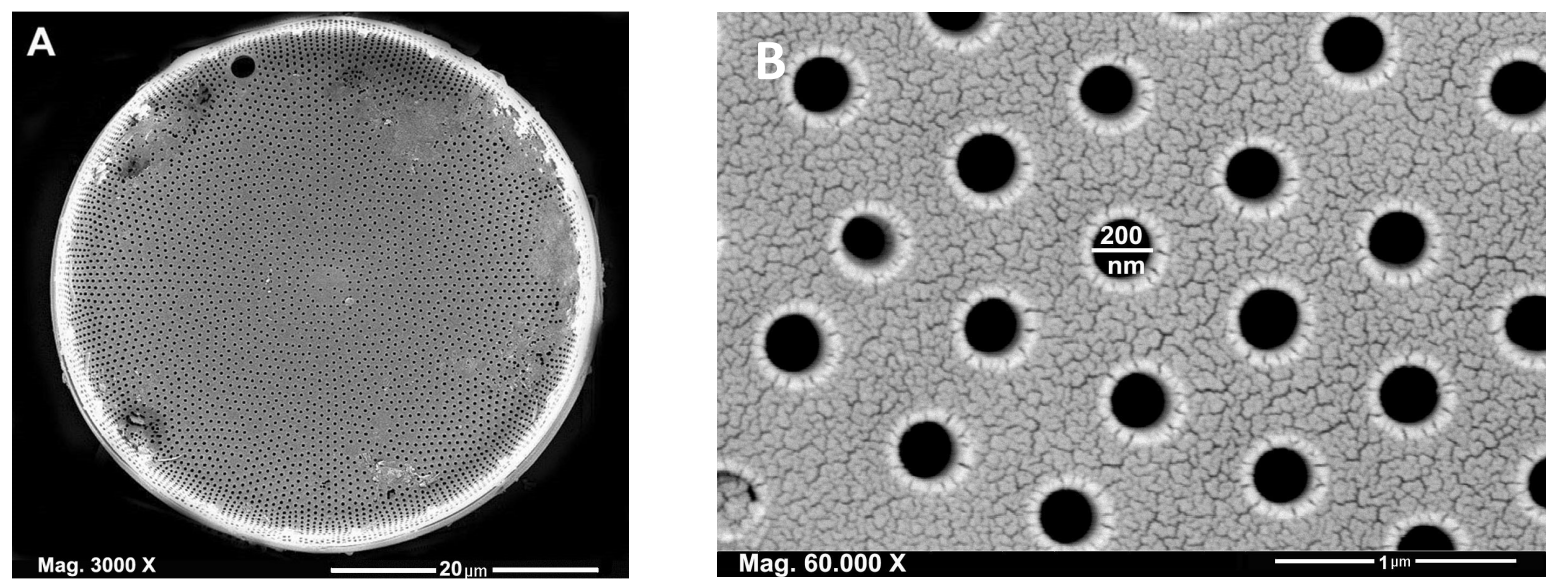

Figure 6: SEM micrographs of Actinocyclus cf. octonarius. (A) Full view ; (B) detail surface of the valve showing nanoporous surface.

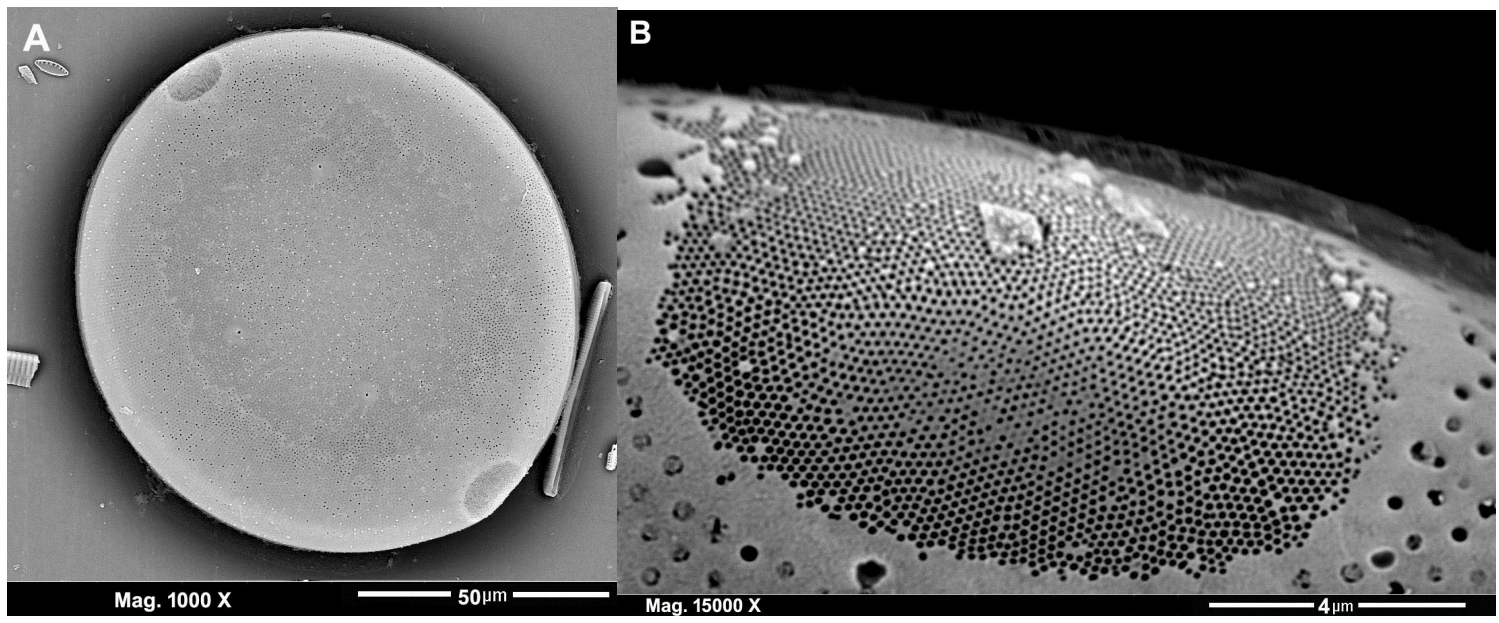

Figure 7: SEM micrographs of Pleurosira lavis. (A) Full view of the frustule; (B) detail surface of the valve showing nanoporous surface in internal view of the valve.

differ from one species to another and their dimensions average from $5-50 \mathrm{~nm}$. That seems like mesoporous nanoparticles covered the areolae in Aulacoseira granulata (Fig. 4 B), which is characterized by areola dimensions with 450 to $500 \mathrm{~nm}$ and the diameter of fine pore ranged between 40 to $50 \mathrm{~nm}$.

These porous structures could retain certain viruses, bacteria and fungal spores. The advantages of such natural mesoporous-like structures can compete at the present established applications of mesoporous silica, such as biological catalysis, size selective protein separations and encapsulation of proteins for drug delivery applications, micro and ultrafiltration applications, as optical chemical sensors. (Bismuto et al. 2008; Hudson et al., 2008; Lee et al., 2009; Sotiropoulou et al., 2005; Hartmann, 2005; Hartmann \& Jung, 2010). Therefore, the valve architecture, face topography, perforation pattern, pore density, diameter of the areolae and fine pores of hymens layers and their size distribution are all important factors that may affect the theoretical selection of certain taxa for certain application. All diatoms that have porosity lower than $1000 \mathrm{~nm}$ could apply for microfiltration to retain bacterial and fungal spores successfully that may help in sterilization of liquids. Moreover it can sort colloidal particles in microfluidic systems, may help to develop new lab on chips with new functions, lower costs and technologically simpler. All diatoms that have hymens layers with porosity lower than $100 \mathrm{~nm}$ like as found in the studied diatom taxa Aulacoseira granulata (Fig. 4), Cyclotella meneghiniana (Fig. 5), could apply for ultra and nano-filteration to retain viruses and successfully applied for drug delivery systems.

The diatom genus Actinocyclous is an example for marine centric diatoms reported from the Mediterranean coast of Alexandria. The frustules of this genus have different porosity scale present at different layers. The 
studied Actinocyclus cf. octonarius frustules have areolae distributed all over the surface with flat or slightly undulated shape. The lattice constant between foramen is $609 \pm 69 \mathrm{~nm}$, which located at the visible light range. The average diameter of foramen is $200 \pm 17.5 \mathrm{~nm}$ (Fig. 6B), which consider below the visible range of light and located at the ultraviolet region of electromagnetic spectrum. That scale confirms the ability of such areolae to diffract visible light. Moreover the hierarchical arrangement of quasi-regular areolae with such lattice constant could work as a diffraction grating. Likewise, there are lattice defects present and distributed over the valve with central large defect (areolae free zone), which differ from central area that existing in other genera such as Coscinodiscus and Thalassiosira. These observations may offer novel optical properties like that had been found in both Coscinodiscus and Thalassiosira (Losic et al. 2007). Therefore, Actinocyclous could be another genus that may has promising ability to integrate in optics, optoelectronics, optical sensors and solar cell systems.

Pleurosira laevis and Cyclotella meneghiniana are brackish water diatom taxa distributed in the freshwater lakes of slightly elevated salinity such as Manzala and Edku lakes. These taxa are another new example of centric diatoms that have nanoporous structure. Pleurosira laevis has one or more occelli at the valve face/mantle junction and two different pattern of porosity present at the same level (Fig. 7 A-B). Areolae on the external valve face are very small and have diameter ranges between 135 to $170 \mathrm{~nm}$. However, the size of porelli present in occelli ranges between 75 to $81 \mathrm{~nm}$. Cyclotella meneghiniana has distinct areolae pattern in marginal zone of the external valve face with different sizes of diameter ranges between 50 to $150 \mathrm{~nm}$. In the internal view, the marginal alveolated chambers are separated by strong costae of thick hyaline silica with variable width. The diameter of fine pores in the alveolated chambers varies between 28 to $35 \mathrm{~nm}$. The nanoporous structure of Pleurosira laevis and Cyclotella meneghiniana may be important for directional sorting of particles in microfluidic systems and could help in prevent clogging. In addition, this nanoporous layer may use in regulation of fluid velocity with microfiltration capability.

\section{Conclusion}

Diatoms are unicellular algae that evolved 130 million years ago and inhabited nearly all aquatic environments of different salinity levels and moist habitats. These organisms produce highly ornamented external shells composed mainly from amorphous silica called "frustules". These frustules display a diversity of patterns and porous silica structures at the nano to micrometer scale and three-dimensional structures. Therefore, the diatom frustules have become one of the most attractive nanoporous materials in nanotechnology. In the present study, SEM and TEM investigations of some selected diatom frustules included Aulacoseira granulata, Cyclotella meneghiniana, Actinocyclus cf. octonarius, and Pleurosira laevis revealed very exciting results where their nanoporous silica sizes are less than $100 \mathrm{~nm}$. The highly ordered $3 \mathrm{D}$ porous silica nanostructures hold promising vicinity for the biological fabrication of nanostructured devices. The nanoporous structures of the studied diatom frustules offer the potential to be used for specialized nano-filtration procedures, supports for catalysis, carriers, supports for chromatography, optical diffraction gratings for sensors, microcapsules for drug delivery and controlled-shape reinforcements for composites, selective adsorption, obtaining the high sensitivity of the sensor and other novel nanotechnological applications.

\section{References}

ASTM, (2012). Standard Terminology Relating to Nanotechnology, ASTM International, West Conshohocken, PA, www.astm.org.

Bismuto, A., Setaro, A., Maddalena, P., De Stefano, L. and De Stefano, M. (2008). Marine diatoms as optical chemical sensors: A time-resolved study. Sensors and Actuators B 130: 396-399.

Crawford, S.A., Higgins, M.J., Mulvaney, P. and Wetherbee, R. (2001). Nanostructure of the diatom frustule as revealed by atomic force and scanning electron microscopy. J. Phycol. 37: 543-554.

Dolatabadi, J.E.N. and de la Guardia, M. (2011). Applications of diatoms and silica nanotechnology in biosensing, drug and gene delivery, and formation of complex metal nanostructures. TrAC Trends in Analytical Chemistry, 2011. 30(9): 1538-1548.

Drexler, K. E. (1986). Engines of creation. Garden City, N.Y: Anchor Press/Doubleday. ISBN: 0-385-19973-2.

Ehrlich, A. (1973). Quaternary diatoms of the Hula Basin (Northern Israel). Bulletin Geological Survey Israel 58: $1-39$.

Ehrlich, A. (1975). The Diatoms from the surface sediments of the Bardawil Lagoon (Northern Sinai)Paleoecological significance. Nova Hedwigia 53: 253277.

Foged, N. (1980). Diatoms in Egypt. Nova Hedwigia 33: 629-707.

Foged, N. (1993). Some diatoms from Siberia, especially from Lake Baikal. Diatom Research 8 (2): 231-279.

Fuhrmann, T., Landwehr, S., El Rharbi-Kucki, M. and Sumper, M. (2004). Diatoms as living photonic crystals. Appl. Phys. B 78: 257-260.

Gasse, F. (1986). East African diatoms. Taxonomy, ecological distribution. Bibliotheca diatomologica 2: 1-201.

Gordon, R. and Parkinson, J. (2005). Potential roles for diatomists in nanotechnology. J. Nanosci. Nanotechnol. 5: 35-40.

Gordon, R. and Tiffany, M.A. (2011). Possible buckling phenomena in diatom morphogenesis, In: Seckbach, J., Kociolek, J.P. (Eds.), The Diatom World. Springer, Dordrecht, The Netherlands, pp. 245-272.

Gordon, R. (2010). Diatoms and nanotechnology: early history and imagined future as seen through patents, In: Smol, J.P., Stoermer, E.F. (Eds.), The Diatoms: Applications for the Environmental and Earth Sciences. Cambridge University Press, Cambridge, pp. 585-602. 
Gordon, R., Losic, D., Tiffany, M.A., Nagy, S.S. and Sterrenburg, F.A.S. (2009). The Glass Menagerie: diatoms for novel applications in nanotechnology. Trends in Biotechnology 27: 116-127.

Hartmann, M. (2005). Ordered Mesoporous Materials for Bioadsorption and Biocatalysis, Chem. Mater., 17: 4577-4593.

Hartmann, M. and Jung, D. (2010). Biocatalysis with enzymes immobilized on mesoporous hosts: the status quo and future trends, J. Mater. Chem., 20: 844-857.

Hudson, S. Cooney, J. and Magner, E. (2008). Proteins in Mesoporous Silicates, Angew. Chem. Int., 47:85828594.

Hustedt F. (1930-1966). Die Kieselalgen. In L. Rabenhorst (ed.), Kryptogamenflora von Deutschland, Oesterreich und der Schweiz, Akademische Verlagsgesellschaft, Leipzig, 1: 1-920, 2: 1-845, 3: 1816.

Hustedt, F. (1957). Die Diatomeenflora des Fluss-systems der Weser im Gebiet der Hansestadt Bremen Abhandlungen des Naturwissenschaftlichen Verein zu Bremen, 34: 181-440.

Krammer, K., Lange-Bertalot, H. (1986-1991). Bacillariophyceae. 1 Teil: Naviculaceae. In: Ettl, H., Gerloff, J., Heynig, H., Mollenhauer, D. (Eds.), Süsswasser-flora von Mitteleuropa, vol. 2(1), pp. 1-876; 2(2), pp. 1-596; 2(3), pp. 1-576; 2(4), pp. 1-437. Gustav Fischer Verlag, Stuttgart and New York,

Lee, C.-H. Lin, T.-S. Mou, C.-Y. (2009). Mesoporous materials for encapsulating enzymes, Nano Today, 4: 165-179.

Losic, D., Pillar, R.J., Dilger, T. Mitchell, J.G. and Voelcker, N.H. (2007). Atomic force microscopy (AFM) characterisation of the porous silica nanostructure of two centric diatoms. Journal of Porous Materials, 14(1): 61-69.

Mann, D.G. (1999). The species concept in diatoms. Phycologia (38): 437-495.

Mishler, J., Blake, P., Alverson, A.J., Roper, D.K. and Herzog, J.B. (2014). Diatom frustule photonic crystal geometric and optical characterization. In: Kobayashi, N.; Ouchen, F.; Rau, I. (Eds), Nanobiosystems: Processing, Characterization, and Applications VII Proceedings Vol. 9171, 27 doi: 10.1117/12.2062287.
Naidu, S. R. (2012)."Towards Sustainable Development of Nanomanufacturing." $\mathrm{PhD}$ diss., University of Tennessee, http://trace.tennessee.edu/utk_graddiss/1330.

Nano. gov, (2015). Manufacturing at the Nanoscale | Nano. [Online] Available at: http://www.nano.gov/nanotech101/what/manufacturing.

Noyes, J., Sumper, M. and Vukusic, P. (2008). Light manipulation in a marine diatom. Journal of Materials Research 23: 3229-3235.

Round, F.E., Crawford, R.M. and Mann, D.G. (1990).The Diatoms: Biology and Morphology of the Genera. Cambridge University Press; Bath: pp. 747.

Simonsen, R. (1979). The diatom system: Ideas on phylogeny. Bacillaria 2: 9-72.

Sotiropoulou, S., Vamvakaki, V. and Chaniotakis, N. A. (2005). Stabilization of enzymes in nanoporous materials for biosensor applications, Biosens. Bioelectron., 20: 1674-1679.

Townley, H.E., Parker, A.R. and White-Cooper, H. (2008) Exploitation of diatom frustules for nanotechnology: tethering active biomolecules. Adv. Funct. Mat. 18: 369-374.

Willis, L., Page, K.M., Broomhead, D.S. and Cox, E.J. (2010). Discrete free-boundary reaction-diffusion model of diatom pore occlusions. Plant Ecology and Evolution, 143 (3) : 297 - 306.

Zalat A.A. (2000). Distribution and paleoecological significance of fossil diatom assemblages from the Holocene sediments of Lake Manzala, Egypt Diatom Res. 15: 167-190

Zalat, A. A. (2002). Distribution and origin of diatoms in the bottom sediments of the Suez canal lakes and adjacent areas, Egypt. Diatom Research, 17(1): 243266.

Zalat, A. A. and Servant-Vildary, S. (2005). Distribution of diatom assemblages and their relationship to environmental variables in the surface sediments of three northern Egyptian lakes. Journal of Paleolimnology, 34: 159-174.

Zalat, A. A. and Servant-Vildary, S. (2007). Environmental change in Northern Egyptian Delta lakes during the late Holocene, based on diatom analysis. Journal of Paleolimnology, 37: 273-299.

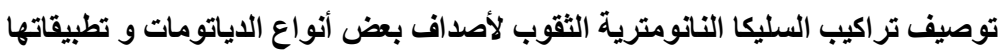

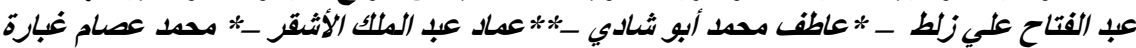

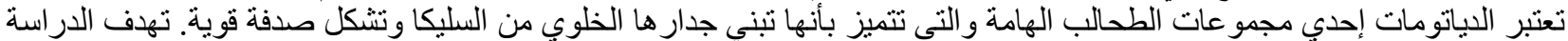

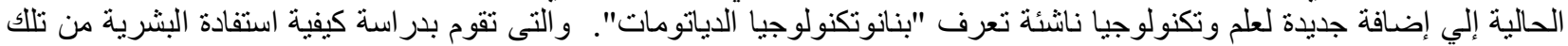

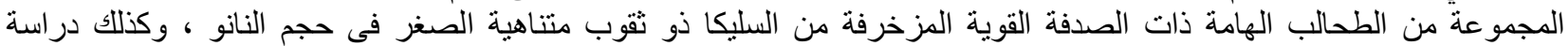

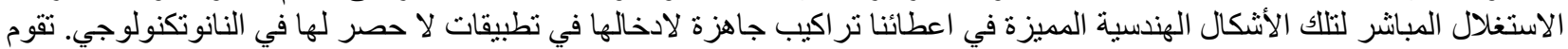

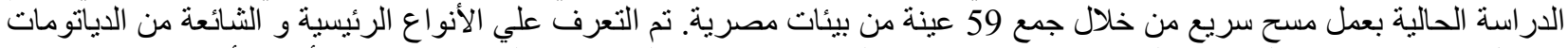

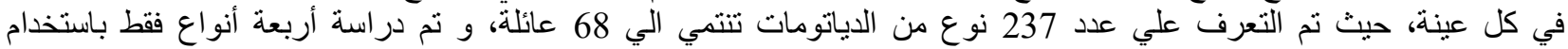

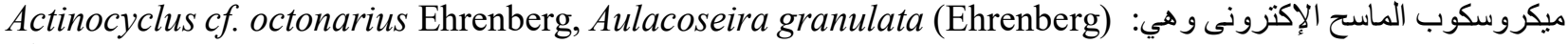
Simonsen, Cyclotella meneghiniana Kützing and Pleurosira laevis (Ehrenberg) Compére تراوحت أقطار الثقوب للانو اع التي تم در استها من 5 إلي 500 نانومتر. نتائج الدراسة تبين أن الدياتومات تستطيع خلق حلول تكنولوجية

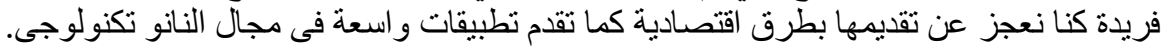

